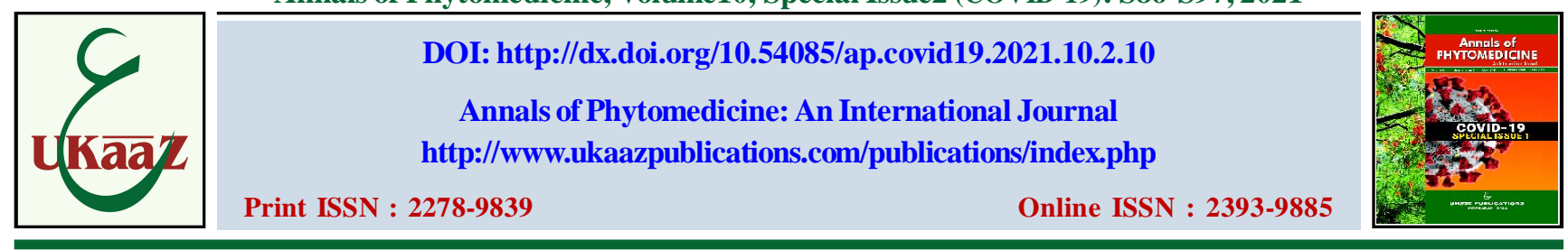

\title{
Genomics-led insight into the coronavirus evolution, pathogenicity and management
}

\author{
Namrata Farwaha, Himangana Das, Richita Saikia, Ricky Raj Paswan, Munmi Phukon*, Rashmi Rekha Baruah**, Ratna \\ Kalita , Priyadarshini Bhorali, Basanta Kumar Borah and Tankeswar Nath \\ Department of Agricultural Biotechnology, Assam Agricultural University, Jorhat-785013, Assam, India \\ *Regional Agricultural Research Station, Assam Agricultural University, Titabor-785630, Assam, India \\ **Faculty of Agricultural Sciences, Arunachal University of Studies, Namsai-792103, Arunachal Pradesh, India
}

\section{Article Info}

\section{Article history}

Received 2 September 2021

Revised 20 October 2021

Accepted 21 October 2021

Published Online 30 December 2021

\section{Keywords}

SARS-CoV-2

COVID-19

Evolution

Vaccine

Bioinformatics

\begin{abstract}
Coronavirus disease 2019 (COVID-19) has so far been the most devastating pandemic ever faced by mankind. Caused by the highly transmissible severe acute respiratory syndrome coronavirus-2 (SARS$\mathrm{CoV}-2$ ), the disease is becoming deadly due to frequent emergence of variants. The virus belongs to the group, Betacoronaviruses, and shares more than $90 \%$ amino acid identity with SARS-CoV. The SARSCoV-2 possess a single-stranded positive-sense RNA which is the largest known viral RNA genome consisting of 25,000-30,000 nucleotides with 14 ORFs. The 3'-region of the genome harbours four structural proteins, namely; the spike, nucleocapsid, envelope and the membrane proteins; the $\mathrm{S}$ protein plays the most important role during infection. Genomics-led studies are pre-requisites to understand the pathogenicity of any pathogen and for devising its management strategies. The availability of SARS-CoV-2 sequence data and suitable bioinformatics platforms have allowed researchers to identify potential therapeutic targets and to predict immune response for accelerating therapeutics and vaccine development. A plethora of such options are available that includes repurposing existing drugs, monoclonal antibodies, anti-inflammatory agents, etc. Moreover, different types of vaccines such as mRNA-based, viral vector, inactivated virus, etc., with different efficacy levels have been approved. However, their efficacy might get compromised with time, particularly due to frequent mutations in the viral genomes. Here, we provide a comprehensive insight into the genome structure, evolution, pathogenicity as well as the achieved success and limitations in management of this notorious virus.
\end{abstract}

\section{Introduction}

The recent outbreak of COVID-19, caused by severe acute respiratory syndrome coronavirus 2 (SARS-CoV-2), has been one of the major pandemics in the known human history (Yang et al., 2020). The coronavirus infection first broke out in Wuhan in Hubei, China in December 2019 and was declared as a Public Health Emergency of International Concern on 30th January, and later, as a pandemic on 11th March 2020; by the World Health Organization (WHO). As of September, 2021, there are more than 231 million confirmed cases of infection and nearly 5 million deaths worldwide due to SARS-CoV-2 (https://coronavirus.jhu.edu/map.html).

Although, the latest pandemic had been the most devastating, coronaviruses, in general, are not new as a threat to human health. To date, there are seven known human coronaviruses ( $\mathrm{HCoVs}$; $\mathrm{HCoV}-$ 229E, OC43, NL63, HKU1, SARS-CoV, MERS-CoV, and SARS-CoV-2) that fall within the alpha- and betacoronavirus genera; and all of them had been reported to be involved in respiratory diseases (Gupta et al., 2020). The earlier known severe acute respiratory syndrome (SARS) coronavirus and middle east respiratory syndrome (MERS)

\section{Corresponding author: Dr. Ratna Kalita}

Assistant Professor, Department of Agricultural Biotechnology, Assam Agricultural University, Jorhat-785013, Assam India

E-mail: ratna.kalita@aau.ac.in

Tel.: +91-9101115207

Copyright $(\odot) 2021$ Ukaaz Publications. All rights reserved.

Email: ukaaz@yahoo.com; Website: www.ukaazpublications.com virus, and SARS-CoV-2 belong to the same genus (betacoronavirus; Anderson et al., 2004). These viruses can infect vertebrates, including human, dogs, cats, mice, rats, swine, rabbits, cattle, horses, bats and cetaceans and birds (chickens, turkeys, and pheasants) (Smith, 2006). The first known case of SARS-CoV infection in human was the one that originated from Guangdong, China in November 2002-03 (Fouchier et al., 2003). Another major outbreak of coronavirus emerged in 2012 as MERS in the Middle East, sharing similar characteristics (Mackay and Arden, 2015; reviewed by Khan et al., 2020); it lead to a major global public health crisis (Peeri et al., 2020). Another virus related to SARS-CoV was discovered in horseshoe bats in 2013, named bat SARS-CoV (Ge et al., 2013). The exact source and natural reservoir of SARS-CoV-2 remains inexplicit, but findings suggest that the open wet markets in Wuhan, China, might have led to the transmission of the latest SARS-CoV-2 from animal hosts to humans (Morrens et al., 2020).

The SARS-CoV-2 can escalate dangerously, thereby opening the way for its global spread (Gupta et al., 2020). With the rise in its spread, SARS-CoV-2 has been frequently undergoing mutations, attributing to the emergence of several newer variants; for example, 501Y.V1 (B.1.1.7) in the UK and 501Y.V2 (B.1.351) in South Africa (Fontanet et al., 2021). Both alpha and beta variants had undergone mutation $(\mathrm{N} 501 \mathrm{Y})$ in the receptor-binding domain of the spike (S) protein, thereby contributing to an increased viral transmission. Two additional mutations (E484K and $\mathrm{K} 417 \mathrm{~N})$ were observed in the S 
protein of the 501Y.V2 variant with capability of immune escape (Wimber et al., 2021). A new emerging lineage, P.1 (501Y.V3), was detected, including another set of mutations (N501Y, E484K and K417T) in Manaus, Brazil (Faria et al., 2021).

\section{Coronavirus genome and evolution}

2.1 SARS-CoV-2 genome structural organization and function

The SARS-CoV-2 has a single-stranded positive-sense RNA (+ssRNA) genome of SARS-CoV-2 is the largest known viral RNA genome consisting of 25,000-30,000 nucleotides. The genome contains a 5'-cap and a 3'-poly-A tail. The 52 untranslated region (UTR) is $265 \mathrm{nt}$ long, while the 3'-UTR is $229 \mathrm{nt}$ long. It has 14 ORFs from 5' to 3' direction (Finkel et al., 2021). ORF-1a/ab at the 5' end; the most fundamental region, encodes the non-structural proteins (Nsps). At the 3' end, the structural proteins: spike (S), envelope (E), membrane $(\mathrm{M})$, and nucleocapsid $(\mathrm{N})$ are prominent; they play significant roles in viral structure integrity, and in the case of the $\mathrm{S}$ protein, viral entry into the host. Along with them, several accessory proteins such as ORF-3b, 6, 7a/b, 8b, 9a/b and 10 are interspersed among them (Gupta et al., 2020) (Figure 1). The ORF-1a/ab gene is approx. 21,300 nt long and encodes replicase polyprotein 1a (pp1a) and polyprotein $1 \mathrm{ab}$ (pp1ab). A -1 frameshift between ORF1a and ORF1b produces the polypeptides pp1a and pplab (Finkel et al., 2021). Each of these polyproteins gets proteolytically cleaved into 16 putative Nsps (Nsp-1 to Nsp-16). The replication-transcription complex (RTC) is formed from these Nsps and is required for viral RNA replication and transcription (Knoops et al., 2008).

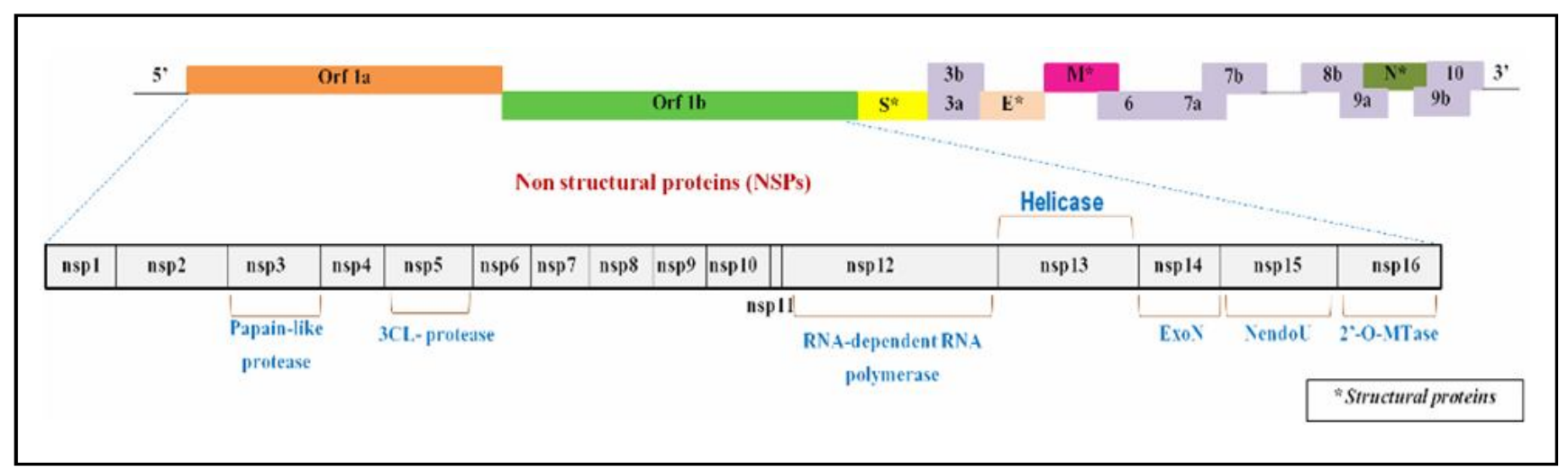

Figure 1: Genome organization of SARS-CoV-2. Different ORFs are shown in different colored boxes and the region harboring the NSPs is shown magnified (adapted from Gupta et al., 2020).

The $\mathrm{S}$ protein $(200 \mathrm{kDa})$ binds to angiotensin-converting enzyme 2 (ACE2) receptors on the host cell surface, facilitating fusion and entry of SARS-CoV-2 into the host cell (Wan et al., 2020). The S protein is extensively $\mathrm{N}$-linked glycosylated, and an $\mathrm{N}$-terminal signal sequence allows it to enter the endoplasmic reticulum (ER). It has two subunits: S1 and S2. The S1-domain consists of the receptorbinding domain (RBD), which enables viral adherence to target cells. This subunit also regulates viral tissue tropism and the host range. The S2 subunit forms the stalk of the S protein and ensures viral entry by mediating the fusion of viral and cellular membranes (de Groot et al., 1987). The most prevalent structural protein in the viral membrane is $\mathrm{M}$ protein $(25-30 \mathrm{kDa})$, which is important for virus assembly and is responsible for shaping the virions (Neuman et al., 2011). The $S$ and $N$ proteins regulate virion size via interacting with the M protein (Gupta et al., 2020). The M protein is a dimer that can take two distinct conformations to increase membrane curvature and facilitating its binding to nucleocapsids (Neuman et al., 2011). According to Fehr and Perlman (2015), the interaction between the $\mathrm{S}$ and $\mathrm{M}$ proteins is crucial for $\mathrm{S}$ protein recognition in the ER-Golgi intermediate compartment (ERGIC)/Golgi complex and new virion assembly. The transmembrane protein, E (approx. 8-12 kDa), is the smallest structural protein; it assists in viral assembly, budding, and release. This protein has an $\mathrm{N}$-terminal ectodomain and a C-terminal endodomain with ion channel function (Armstrong et al., 1984). Recombinant CoVs lacking E protein have been demonstrated to have lower viral titers, slowed viral maturation, or to generate incompetent offspring, highlighting its relevance in virus synthesis and maturation. Because of its unique function, it was proposed that such recombinant $\mathrm{CoV}$ s lacking $\mathrm{E}$ protein could be useful in generation of live attenuated SARS-CoV vaccines (Ortego et al., 2002). The $\mathrm{N}$ protein $(46 \mathrm{kDa})$ is involved in genome encapsidation, packaging of the viral genome into a ribonucleoprotein complex (nucleocapsid). It is CoV's sole protein that binds to the virus's genome. It is required for timely virus replication and transmission. It is gaining importance in pathogenicity as an interferon (IFN) inhibitor (Cui et al., 2015). It is considered as a significant antigen because of its abundance in the host during infection. Its high antigenicity had been used to develop SARS-CoV rapid-diagnosis kits (Chang et al., 2006).

\subsection{Coronavirus diversity, evolution and divergence}

Coronaviruses belong to order Nidovirales; subfamily, Coronavirin, and family, Coronaviridae. They are viruses of 80-120 nm in diameter (Cascella et al., 2020; Villas-Boas et al., 2020). This group of viruses infect a wide range of mammalian hosts, and and affect their respiratory system, liver, intestine, kidney, and central nervous system. The previously classified three subfamilies, group 1 (mammalian $\mathrm{CoV}$ ), group 2 (mammalian $\mathrm{CoV}$ ), and group 3 (avian $\mathrm{CoV}$ ) (reviewed by Villas-Boas et al., 2020) have been renamed into alfacoronavirus (group 1), betacoronavirus (group 2) and gammacoronavirus (group 3) by International Committee for Viral Taxonomy. The recently classified fourth subfamily is delta coronavirus (group 4, birds and pigs $\mathrm{CoV}$ ) (reviewed by Villas-Boas et al., 2020).

The SARS epidemic has made groups across the globe to study the exact time point of interspecies transfer of SARS-CoV from civets (Bovine CoVs, BCoVs) to humans (HCoV-OC43) (Vijgen et al., 
2006). Several novel coronaviruses in humans and animals have been discovered and their rate of evolution and time of divergence within the Coronaviridae family had been estimated using the BEAST program, gene sequences (ORF1ab, S, nucleocapsid), and datasets contributed by research groups (Vijgen et al., 2006; Pyrc et al., 2006; Vijaykrishna et al., 2007; Hon et al., 2008; Patrick et al., 2010). The $\mathrm{S}$ and nucleocapsid genes in porcine hemagglutinating encephalomyelitis virus (PHEV), BCoV, and $\mathrm{HCoV}-\mathrm{OC} 43$ showed different evolutionary rates. There was 100 years difference between the time of divergence of PHEV lineage from that of $\mathrm{HCoV}-\mathrm{OC} 43$ and BCoV lineage (Vijgen et al., 2006). Using the helicase gene sequence, the evolutionary history of coronaviruses was estimated to be of about 420 years (Vijaykrishna et al., 2007). By aligning a big dataset of SARS-Rh-BatCoV ORF1 sequences, the evolutionary time for human SARS-CoV was estimated to be in the year 1972 which was 31 years before the SARS epidemic, and civet SARS-CoV in 1995 and the most recent time point for both human and civet SARS-CoV was estimated to be in 2001 (Lau et al., 2010; Patrick et al., 2010).

The $\mathrm{BCoV}$ has been reported to be the closest to the human $\mathrm{CoV}$ (hCoV) (Vijgen et al., 2006). SARS-CoV-2 has $88 \%$ similarity with bat SARS-like CoV (bat-SL-CoVZC45 and bat-SL-CoVZXC21), 79\% with SARS-CoV, and 50\% with MERS-CoV. However, the S protein gene of SARS-CoV-2 has only $75 \%$ similarity with bat-SL-CoVZC45 and bat-SLCoVZXC21 (Lu et al., 2020). There is 76\% sequence similarity between the Wuhan-Hu-1 and SARS-CoV S strain Tor2 (Jaimes et al., 2020).

Nucleotide sequence similarity studies have reported $99.98-100 \%$ identity among SARS-CoV-2, SARS-CoV and MERS-CoV, indicating that the virus has shifted to humans recently (Tizaoui et al., 2020). The sequences of SARS-CoV and SARS-CoV-2 are highly similar. The $\mathrm{B}$ and T cell epitopes for SARS-CoV-2 showed higher homology with SARS-CoV too (Grifoni et al., 2020). An insight into these potential regions is a step-forward move towards understanding the immune response of SARS-CoV-2 which would facilitate planning and designing of vaccines against coronavirus (Grifoni et al., 2020; Tizaoui et al., 2020).

\section{Coronavirus pathogenicity}

SARS-CoV-2 typically infects human alveolar type II cells and bronchial epithelial cells, where it attaches to the surface receptor ACE2 via the S glycoprotein on its surface (Qian et al., 2013; Zhou et al., 2020). Following this attachment, proteolytic cleavage occurs within the S2 subunit which is induced by the cell surface-associated transmembrane protease serine 2 (TMPRSS2), cathepsin, or another protease (Qian et al., 2013). The fusion of the virus with the host cell membrane is triggered by this conformation alteration in the $\mathrm{S}$ protein, ensuring viral entry through endocytosis (Romano et al., 2020). The virus then releases its genomic RNA into the cytosol/ cytoplasm of the host cell.

The coronaviruses affecting humans are mostly alpha-CoVs (HCoV229E and HCoV-NL63) and beta-CoVs of strain A (HCoV-OC43 and HCoV-HKU1) (Villas-Boas et al., 2020) that cause varying degrees of severity in humans with respiratory and non-respiratory infections. These variants cause upper respiratory infection limited to self and cause common colds which are easily fought back by the human immune system without needing any medical attention (Villas-Boas et al., 2020). A person with weak immunity and elder age shows symptoms of lower respiratory tract infection along with common cold. The mortality rate in case of SARS-CoV infection is about $10 \%$ while that in case of MERS-CoV is about 35\% (Cascella et al., 2020). The SARS-CoV-2 virus has a higher affinity to bind to the host than SARS-CoV due to the modification of its viral $\mathrm{S}$ protein, among other structural proteins which results in enhanced transmission (Zhou et al., 2020). The host response severity depends on an innate response to viral recognition which involves the expression of type-1 IFNs and pro-inflammatory cytokines (Prompetchara et al., 2020). Viral proliferation can lead to the large-scale recruitment of neutrophils and monocyte macrophages to the lungs. If the antiviral response is delayed or inhibited, it leads to a hyper-inflammatory environment (Prompetchara et al., 2020). Huang et al. (2020) found that levels of IL-1B, IL-1RA, IL-8, IL-10, IFN-gamma, IP10, MCP1, and MIP1s are higher in COVID-19 patients than in healthy adults.

The commonality between the epidemics that happened in 2002 and 2003 was the interspecies viral transmission; for example, from Chinese ferret-badger (Melogale moschata), masked palm civet (Paguma larvata), and raccoon dog (Nyctereutes procyonoides) to humans (Guan et al., 2003). SARS-CoV is believed to be a recombination between these CoVs when transfected to humans from animals. The seafood market in China might not be the main source of CoV (Perlman and Netland, 2009; Villas-Boas et al., 2020) as the investigations showed negative results when tested for the presence of SARS-CoV in masked palm civet in either domestic or wild type (Poon et al., 2009). A SARS-CoV like CoV has been found in Chinese horseshoe bat (Rhinolophus spp.) (Li et al., 2005; Lau et al., 2005; Villas-Boas et al., 2020) which were available in the animal market in China. The study suggests possible transmission of the $\mathrm{CoV}$ from this bats to animals like masked palm civets and then to humans (Perlman and Netland, 2009). Genetic variations in the SARSCoV-2 and ACE2 receptor can affect the transmission, clinical manifestation, mortality, and efficacy of drugs and vaccines for COVID-19. The high transmissions and progressive disease of SARSCoV-2 in a small but significant proportion of infected individuals might be contributed by some genetic factors. Large scale studies in populations of geographically diverse ancestry have demonstrated substantial genetic variation in viral protein-coding regions, with widely varying allele frequencies (Lek et al., 2016). The SARS-CoV$2 \mathrm{~S}$ protein binds ACE2, the host cell receptor, with a 10 - to 20 -fold greater affinity compared to SARS-CoV, and contains a polybasic furin cleavage site resulting from a unique insert to SARS-CoV-2 that could enhance infectivity compared to SARS-CoV-2 and MERS (Ayal et al., 2020). The conformational change in the $\mathrm{S}$ protein between the $\mathrm{S} 1$ and $\mathrm{S} 2$ domains favours the binding to the ACE2 receptor, and thus increases the probability of infection (Plante et al., 2021). The D614G mutation in the $S$ protein was peculiar found in the most infectious form of SARS-CoV-2 (Callaway et al, 2021). SARS-CoV-2, being an RNA virus, is prone to mutations as they are copied inside their hosts, because enzymes that copy RNA are error-prone. Many mutations are neutral; however, a few mutations may benefit the virus leading to increased transmissibility, higher infectivity, and higher virulence resulting in severe disease, immune/vaccine escape, or any their combinations (Novelli et al., 2021). The failure of tests such as RT-PCR could be due to the mutations in a region of the genome targeted. Mutations in the RBD of the S protein allowed the virus to escape recognition by antibodies and were not detected for months. Different variants have been detected around the world with mutations in the $S$ protein which appears to increase the transmissibility of SARS-CoV-2. These sequence changes has raised 
concerns among vaccine researchers due to their location in or close to the RBD; thus affecting other neutralizing antibodies target, the $\mathrm{N}$-terminal domain.

\section{Fighting the coronavirus: Drug based and non-drug strategies}

\subsection{Bioinformatics for drug designing against SARS-CoV-2}

The coronaviruses that can infect humans are expected to follow a pattern of evolution and widen their host range to animals. Getting deeper into the evolutionary history of the virus, tracing the virus across hosts and looking for similarity of other viruses to SARS-CoV2 is a prerequisite to such investigations (Khadraoui, 2020; Hufsky et al., 2021).

The Microbiome Informatics Team Leader at EMBL-EBI adopted their online resource MGnify to bring different RNA fragments together to look for the presence of coronavirus in a sample The
Virify pipeline within this package had been adopted as a new virus identifier for coronavirus detection (Hufsky et al., 2021). Different bioinformatics centres including resources at EMBL-EBI have dedicated cells for coronavirus research for development of viral sequence databases. For example, the SARS-CoV-2 genome browser in Ensembl has SARS-CoV-2 reference genome, Rfam database for RNA families has COVID-19 sequence data for RNA annotation and secondary structure prediction, UniProt has resources for viral and human protein sequences pertinent to the disease, while the COVID19 Data Portal in EMBL-EBI is dedicated to data submission and open access (Khadraoui, 2020). The portal has grown into a huge resource site with open access to nearly 0.2 million scientific publications on COVID-19 contributed by some 300 research centres from about 30 countries (Khadraoui, 2020; Hufsky et al., 2021). Some of the bioinformatics resources that are being extensively used for coronavirus genomics investigation and drug designing are presented in Figure 2.

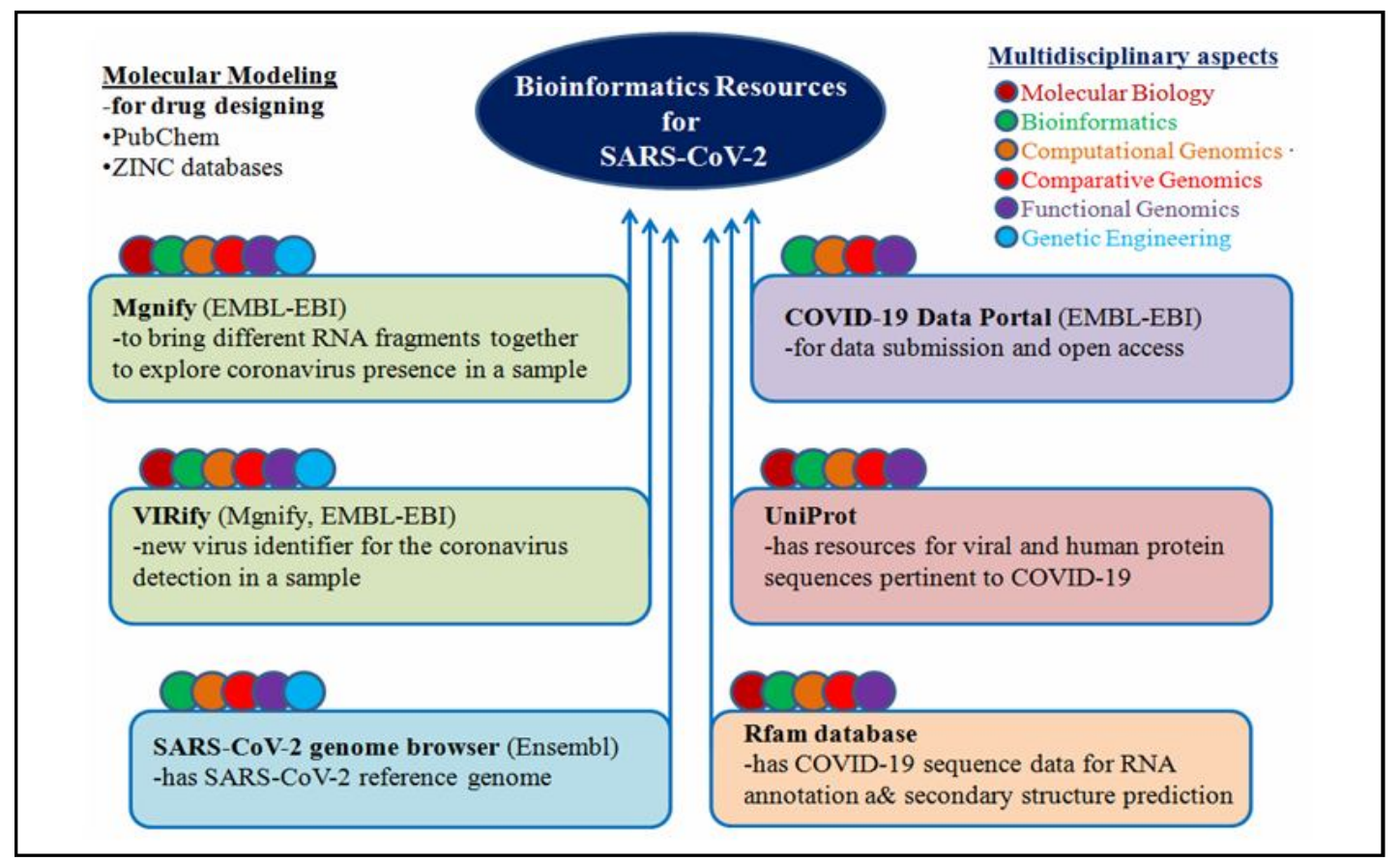

Figure 2: Application of bioinformatics in coronavirus genomics investigation and drug designing.

Extensive molecular studies for comparison of SARS-CoV, MERS$\mathrm{CoV}$, and SARS-CoV-2 have been going on to understand the viral protein and human protein interaction, viral protein localization in the host cells, and any common weaknesses in all these three viruses (Khadraoui, 2020; Hufsky et al., 2021). Potential targets for drugs have been identified which were common to SARS-CoV, MERS-CoV, and SARS-CoV-2, and a selection of drugs has been identified for repurposing in COVID-19 treatment (Gordon et al., 2020). The discovery of bioactive compounds for cost-effective drug designing within a short period has been possible because of the molecular modelling which facilitated pre-selection in binding efficacy of the drug molecules to the target molecule of interest (Villas-Boas et al., 2020). Molecular modelling has supported structure-based planning for drugs in designing the target molecule against the virus. In the virtual process of finding the hits, the databases such as PubChem (https://pubchem.ncbi.nlm.nih.gov/) (Kim et al., 2019) and ZINC databases (https://zinc.docking.org/) (Irwin and Shoichet, 2005) provide the origin and molecular structure of the compounds for screening (Villas-Boas et al., 2020). More than 300 candidate inhibitors against SARS-CoV-2 main protease (Mpro) were identified using PubChem and ZINC databases by molecular docking to understand the target-ligand complex (Ortega et al., 2020), and found PubChem CID 444,745 with higher efficacy in inhibiting the enzyme (Villas-Boas et al., 2020).

Conserved structured elements have been shown to play critical functional roles in the life cycles of coronaviruses (Yang and Leibowitz, 2015). Through, direct interactions with host RNA-binding proteins and helicases, structural elements add a layer of complexity to the regulatory information that is encoded in the viral RNA. Highly conserved RNA structural elements have been identified in several 
viral families, many of which have been functionally validated (Jaafar and Kieft, 2019). Some of these are stem-loops in the 5'-UTR of SARS-CoV-2 structural elements which are conserved across betacoronaviruses and are known to impact viral replication (Yang and Leibowitz, 2015). Rangan et al. (2020) identified 106 structurally conserved regions that would be suitable targets for unexplored antiviral agents. Moreover, they predicted at least 59 unstructured regions that are conserved within SARS-CoV-2. Programmed -1 ribosomal frameshifting $(-1 \mathrm{RF})$ is an essential regulating mechanism of translation used by SARS-CoV to synthesize the key replicative proteins. The integrity of RNA pseudoknot stability and structure in the -1 RF site is important for efficient -1 RF. Thus, small molecules interacting with high affinity and selectivity with the RNA pseudoknot in the -1 RF site of SARS-CoV (SARS-pseudoknot) would disrupt -1 $\mathrm{RF}$ and be fatal to viral infectivity and production. Park et al. (2011) discovered 43 RNA pseudoknot-binding ligand that inhibit the -1 ribosomal frameshifting of SARS-coronavirus by structure-based virtual screening.

\subsection{Generative approaches for drug designing}

Variational autoencoder (VAE) is a generic model for enhancing the diversity of generated data. Autoencoders instruct molecules into a vector that captures properties such as bond order, element and functional group (Bjerrum and Sattarov, 2018). Chenthamarakshan et al. (2020) demonstrated a VAE that captures molecules in a latent space. Once captured, variations are made on the original molecule vectors based on desired properties; these can then be decoded back into novel molecules. To optimize the structures, quantitative estimate of druglikeness, synthetic accessibility, and $\operatorname{LogP}$ regressors were used to improve the latent space variations. In a different approach, many of the issues were solved with traditional generative models by developing a novel advanced deep Q-learning network with fragment-based drug design (Tang et al., 2020). This allowed for the enhanced exploration of space by assembling SARS-CoV-2 molecules one fragment at a time rather than relying on latent space adjustments. After making connections and rewarding molecules with the most drug-like connections, a pharmacophore and descriptor filter was used to refine the set. Tang et al. (2020) demonstrated a robust method for designing novel, high-binding compounds refined to the structure of SARS-CoV-2 3CLPro. The names of few drugs and their mechanism of actions are mentioned in Table 1.

\subsection{Artificial intelligence-based drug discovery}

The scale and efficiency that artificial intelligence (AI) brings to drug discovery are especially relevant for treating the COVID-19 (Mei and Tan, 2021). Beck et al. (2020) published an application of their Deep Learning-based drug-target interaction model that predicted commercially available antiviral drugs that may target the SARS$\mathrm{CoV}-2$ related protease and helicase. In another study, 332 interactions had been identified between SARS-CoV-2 proteins and human host proteins including ACE2, Furin, TMPRSS2, NRP1, eEF1A, etc. (Gordon et al., 2020). Zeng et al. (2020) proposed that the AOPEDF (arbitrary-order proximity embedded deep forest approach) algorithm can predict novel drug-target interactions. AI algorithms were used to identify baricitinib which is an approved Janus kinase (JAK) 1 / JAK2 inhibitor, for treating rheumatoid arthritis, to be effective at inhibiting SARS-CoV2 infection as well as reducing virus-induced inflammation (Stebbing et al., 2020). In silico molecular modelling suggests that several FDA-approved anticancer drugs (Capmatinib, Pemigatinib, Selpercatinib, and Tucatinib) might be able to inhibit COVID-19 by docking on Mpro and S of SARS-CoV-2 (Parveen and Alnoman, 2021).

Table 1: Available drugs in use against SARS-CoV-2 and their mechanisms of action

\begin{tabular}{|c|c|c|c|c|c|}
\hline \multirow[t]{2}{*}{ Name } & \multicolumn{3}{|c|}{ Trials } & \multirow{2}{*}{$\begin{array}{c}\text { Approved/ } \\
\text { not approved }\end{array}$} & \multirow[t]{2}{*}{ Reference } \\
\hline & Clinical & In vivo & In vitro & & \\
\hline Apilimod & SARS-CoV-2 & $\mathrm{N}$ & SARS-CoV-2 & NA & Riva et al., 2020 \\
\hline MDL-28170 & $\mathrm{N}$ & $\mathrm{N}$ & SARS-CoV-2 & NA & Riva et al., 2020 \\
\hline ONO 5334 & $\mathrm{~N}$ & $\mathrm{~N}$ & SARS-CoV-2 & NA & Riva et al., 2020 \\
\hline Imatinib & $\mathrm{N}$ & $\mathrm{N}$ & SARS-CoV-2 & Yes & Han et al., 2021 \\
\hline Mycophenolic acid & $\mathrm{N}$ & MERS-CoV & $\begin{array}{c}\text { MERS-CoV, HBV, HCV, } \\
\text { arboviruses (JEV, WNV, } \\
\text { YFV, dengue virus and } \\
\text { CHIKV) }\end{array}$ & Yes & Han et al., 2021 \\
\hline Quinacrine Dihydrochloride & $\mathrm{N}$ & $\mathrm{N}$ & SARS-CoV-2 & Yes & Han et al., 2021 \\
\hline
\end{tabular}

\subsection{Use of antivirals and immunity against COVID-19}

To tackle the increasing number of COVID-19 cases, use of antivirals has been adopted as the primary means. Antivirals are chosen based on their high potency and a high therapeutic index, i.e., their effectiveness against the virus. Moreover, the antivirals should be non-toxic to the host. They must also have a high barrier to resistance as well as a universal ability to target a population of viral variants (Chan, 2020). Among the two types of antivirals (direct-acting antivirals, DAAs and host-targeting antivirals, HTAs), DAA drugs were used as complement vaccines against some SARS-CoV-2 variants, especially, in synergistic combinations (Chan, 2020; Pelly and Liotta, 2021). Such kinds of therapeutic agents are used to suppress disease progress in actively infected patients, also they can be used prophylactically to minimize new infections ratio. In 2020, several therapies including Remdesivir, Casirivimab/Imdevimab, Baricitinib/ Remdesivir, Bamlanivimab, and convalescent plasma therapy were granted Emergency Use Authorization by the FDA. Many laboratories are attempting to develop DAAs that could suppress viral replication in COVID-19 positive patients (Pelly and Liotta, 2021). 
Some of the DAAs used in COVID-19 are:

(i) Protease inhibitors like Lopinavir, Ritonavir, Darunavir, Danoprevir, and the experimental drug ASC-09.

(ii) Broad-spectrum antivirals include commonly used Umifenovir, which is largely licensed in China and Russia for influenza (Poveda et al., 2014).

(iii) RdRP inhibitor includes Favipiravir which is an oral antiviral.

(iv) Nucleosidase and neuraminidase inhibitors like Oseltamivir, Ribavirin and Azvudine.

(v) Polymerase Acidic Endonuclease Inhibitors like Baloxavir Marboxil.

The HTAs complement the DAAs, but are superior in several aspects. In the replication of several types of viruses, specific host proteins play crucial roles. Some types of HTAs are likely to be effective against the newly emerging viruses as they might leverage the same host protein for replication (Mei and Tan, 2021). The key step of the life cycle of SARS-CoV-2 is entering into host cells; therefore, blocking this step is critical for preventing the infection. Two mucosaspecific proteases, TMPRSS2 and TMPRSS4, catalyze the cleavage of SARS-CoV-2 S and trigger virus entry into host cells (Zang et al., 2020). Pegylated interferon alfa- $2 \mathrm{a}$ and $-2 \mathrm{~b}$ alone and in combination with other antiviral agents, approved for treating hepatitis B virus and hepatitis $\mathrm{C}$ virus infection could be used to stimulate innate antiviral responses in COVID-19 patients. One research showed that type I and type III IFN have potential inhibitory effects on SARSCoV-2 in vitro (Felgenhauer et al., 2020). Understanding the RNA virus and its interactions with host proteins could improve therapeutic interventions for COVID-19. Recently, Sun et al. (2021) reported the generation of in vivo structure maps and models of the SARS-CoV-2 RNA genome. They determined the SARS-CoV-2 genome structure in infected human cells and from refolded RNAs that enabled prediction of host proteins binding to viral RNA using a deep-learning tool, and identification of FDA-approved drugs for repurposing to reduce SARS-CoV-2 infection in cells.

Lately, there have been considerable interest and research in preventing the coronavirus infection by increasing general immunity, and several traditional herbs are being explored. The roles of medicinal and aromatic plants (Mehrotra, 2020), sesame and flaxseeds (Ahmad and Ghosh, 2020) and spices (Palai et al., 2020) as immunity boosters and potential prophylactic measures against COVID-19 have been elaborately reviewed recently.

\subsection{Vaccine-based strategies to combat COVID-19}

Development of a therapeutic antibody response in the host is the prerequisite for successful vaccine production. The process of vaccine development includes preclinical animal trials, phase I to III trials and studies on its ability to stimulate antibodies in human and finally, large scale production. Several vaccine projects have been successful in preclinical, phase I and phase II trials using recombinant DNA, mRNA, S protein subunits, virus like particles, viral vectors, and live attenuated viruses. According to WHO, as on January $5^{\text {th }}, 2021$, there are 63 candidate vaccines in human clinical trials and more than 172 candidates in preclinical stage worldwide against SARS-CoV-2. Among the evaluated vaccines, 13 candidates have entered phase III clinical trials. In less than a year, different types of vaccines against SARS-CoV-2 infection were made and approved with different efficacies; they are BioNTech/Pfizer (95\%), Moderna (94.1\%), Gamaleya (Sputnik V) (91.6\%), Bharat Biotech, 2021 (Covaxin) (81\%), etc. (Novelli et al., 2021). Some approaches, being followed for the development of an effective and safe vaccine against COVID19 , include the followings.

\subsubsection{Live attenuated vaccines}

Live attenuated vaccines (LAV) targeting several others viruses had been successful and are currently in clinical development for SARS$\mathrm{CoV}-2$. Attenuation is achieved by inducing mutation into the viral protein. It can generate $\mathrm{T}$ cell and $\mathrm{B}$ cell response, however is generally not suitable for immunocompromised individual. For example, Indian Immunological Limited is currently working together with Griffith University to develop a vaccine using codon deoptimization as a strategy against SARS-CoV-2. Such a candidate provides a long-lasting immunity against SARS-CoV-2 following a single shot $(\mathrm{Ng}$ et al., 2020). Del-NS1-SARS-CoV2 is an influenza based vaccine which is attenuated by deletion of a virulent element of the non-structural 1 gene. It is more immunogenic than the wild type virus and can be given as nasal spray (Kaur et al., 2020). An attenuated influenza virus was also modified to encode the RBD of SARS-CoV-2 S protein (Krause et al., 2020).

\subsubsection{Inactivated vaccines}

Inactivated vaccines (IVs) are produced by inactivating the virus molecule with heat, radiations (UV light) or chemicals which result in the production of a safe vaccine, especially for immuno compromised persons. These vaccines induce weaker immune responses than LAVs and need several booster doses. However, their production is time consuming, as the virus needs to be cultured in the lab and then inactivated (Xia et al., 2020). CoronaVac is an IV candidate, developed by the China's vaccine manufacturer, Sinovac Biotech. CoronaVac is made with beta-propiolactone as an inactivating agent and formulated with aluminium hydroxide as an adjuvant (Lim et al., 2020). Inactivated SARS-CoV-2 viruses possess the RBD within S protein as an immune inducer which is a popular immune inducer (Xia et al., 2020). With the safety and immunogenicity results from phase I and II clinical trials, this vaccine has achieved an efficacy of $50.7 \%$ in phase II and also received Conditional Marketing Authorization (CMA) in China (SinoVac, 2021). Another example of an inactivated vaccine is Beijing Bio-Institute of Biological Products Coronavirus Vaccine (BBIBPCorV) produced by Sinopharm in China. It exhibited satisfactory results in early trials and had entered phase III trials (Xia et al., 2021). It had achieved an efficacy of $79.3 \%$ and received CMA in China. Covaxin developed by Bharat Biotech, Indian Council of Medical Research and National Institute of Virology, is India's first inactivated vaccine against COVID-19. The vaccine produces robust immune responses. Recently, Bharat Biotech has announced the phase III results of Covaxin that showed $81 \%$ interim efficacy in preventing COVID-19 in persons without prior infection after second dose.

\subsubsection{Nucleic acid (DNA and mRNA based) vaccines}

Nucleic acid vaccines introduce genetic instructions in the form of DNA or mRNA encoding disease-specific antigens to host cells and generate immunogens by utilizing the protein making machinery of the same. In situ synthesis of these foreign immunogens in the host cells elicits both antibody production and $\mathrm{T}$ cell induction providing protection against COVID-19 (Zhu et al., 2020). DNA vaccines use 
plasmid DNA containing mammalian expression promoter and transgene encoding protein antigen, such as S protein of COVID-19 vaccines. No DNA vaccine has yet been approved against SARS-CoV2, but 11 candidates are in clinical trials (Tebas et al., 2021). Inovio Pharmaceuticals, US, collaborating with Beijing Advaccine Biotechnology, University of Pennsylvania, University of Texas, Twist Biosciences and Lavalle University have developed the INO4800 DNA vaccine (Chen et al., 2020). It was designed to optimize the $\mathrm{S}$ protein sequence of SARS-CoV-2 virus. The presence of humoral and $\mathrm{T}$ cell response in the preclinical trials demonstrates that INO4800 can produce an effective immune response.

The mRNA-based vaccines induce the strongest immune response by mimicking a natural infection. US based Moderna and National Institute of Allergy and Infectious Diseases Vaccine Research Centre have developed mRNA-1273, a lipid nanoparticle encapsulated SARSCoV-2 vaccine (Moderna, 2020). The encapsulated mRNA-1273 travels to the immune cells (lymph nodes) and instructs them to make copies of the $\mathrm{S}$ protein on their surface as if SARS-CoV-2 infects them and on the other side, immune cells discover the $\mathrm{S}$ proteins and prepare themselves for future response against SARSCoV-2 virus (Saini et al., 2020). Another mRNA based vaccine candidate is BNT162b2, developed by Pfizer, in collaboration with Germanbased BioNTech and Shanghai-based Fosun Pharma. This vaccine had also been developed to instruct immune cells to make several copies of the full-length SARS-CoV-2 S protein.

\subsubsection{Protein subunit vaccines}

By using viral $\mathrm{S}$ protein, Clova Biopharmaceuticals, China, in collaboration with GlaxoSmithKline, UK, have developed SARS-CoV$2 \mathrm{~S}$ protein trimer candidate (Alvi et al., 2020). The full-length $S$ protein, present in the Trimer-Tag Technology, elicited an immune response ultimately preventing the entry of viral particles through host ACE2 receptor. US-based Generex and Epivax have identified SARS-CoV-2 amino acid peptides and would utilize the li-Key peptide technology for the synthesis of COVID-19 vaccine (Perez et al., 2010).

\subsubsection{Viral vector vaccines}

The viral vector vaccines use non-pathogenic viral vectors to deliver antigen-coding DNA fragment to host cells for expression of antigen. These vaccines provide prolonged and enhanced protein expression and therefore, have better prophylactic use. Such vaccines can trigger the cytotoxic T-cells, leading to removal of infected cells (Shirley et al., 2020). Viral vectors are grouped under two categories: replicating viral vectors and non-replicating viral vector. These vectors are safe, genetically stable and do not integrate into host genome. The University of Oxford, UK, and Astra Zeneca had developed AZD1222 (ChAdOx1 nCoV-19) which is a SARS-CoV-2 vaccine candidate that used a chimpanzee adenovirus as a vector (ChAdOx1) modified to induce the S protein from SARS-CoV-2 (Kyriakidis et al., 2021). It was one of the first vaccine candidates to begin clinical trials and the only one using a debilitated chimpanzee adenovirus platform.

\subsubsection{Virus like particle vaccines}

The only vaccine candidate against COVID-19 employing this strategy was designed by the Quebec-based Medicago (coVLP) that aims to combine the efficacy of attenuated vaccines with the safety usually displayed by subunit vaccines. The approach used by Medicago uses virus-transfected Nicotiana benthamiana plant to express the prefusion trimeric subunit form of the $\mathrm{S}$ protein and assemble it on the surface of virus-like particles which are harvested and used (Kyriakidis et al., 2021).

\subsection{Other non-drug strategies against COVID-19}

\subsubsection{Therapeutic antibodies}

Several monoclonal antibodies against SARS-CoV-2 isolated from infected patients in recovery and convalescent periods can recognize $\mathrm{RBD}, \mathrm{N}$ terminal domain, and S2 domain of S protein. Ju et al. (2020) isolated three potent antibodies P2C-1F11, P2C1A3, and P2B-2F6, which compete with ACE2 for binding to SARS-CoV-2 RBD without cross-reacting with plasma from SARS-CoV and MERS-CoV patients. $\mathrm{P} 2 \mathrm{C}-1 \mathrm{~F} 11$ displays the most potent neutralizing activity in vitro and in vivo among them. Chi et al. (2020) isolated a monoclonal antibody, 4A8, from a convalescent patient that neutralized both authentic SARS-CoV-2 and SARS-CoV-2 pseudovirus. A neutralizing antibody cocktail REGN-COV-2 reduced viral load and enhanced immune responses (NCT04425629) (Weinreich et al., 2021). Several antibodies targeting SARS-CoV-2 S protein are still undergoing trials for COVID-19 treatment; further research in ongoing (Yang et al., 2020).

\subsubsection{Interferon (IFN) therapy}

IFNs are natural antiviral molecules and immune modulating agents that inhibit viral replication and induce both innate and adaptive immune responses. Recombinant IFN-alpha was effective in treating SARS-patients in earlier trials (Loutfy et al., 2003). Earlier, in a set of trials, administering Type I IFN, Alfacon, along with a corticosteroid, resolved $50 \%$ of lung abnormalities and reduced impaired oxygen saturation associated with various respiratory diseases (Seesuay $e t$ al., 2018). For elongated use, the intravenous immunoglobulin could be a safe immunomodulator in patients of all age groups. It inhibits cytokine production and increases generation of anti-inflammatory mediators (Gilardin et al., 2015). For effective control of SARS, thymosin alpha-1 (Ta-1) had been reported to be a potential immune booster (Kumar et al., 2013). Therefore, these two alternatives had been considered promising against SARS-CoV-2 infection as well.

\subsubsection{RNA-interference mediated gene silencing}

Several gene silencing approaches targeting key proteins of coronaviruses had shown promises to inhibit replication of SARS$\mathrm{CoV}$ in Vero E6 cell line of African green monkey kidney (Lundstorm, 2020). In another RNAi therapeutics effort against SARS-CoV, kidney FRhK4 cells of foetal rhesus monkey were transfected with siRNA before or after viral infection; prophylactic inhibition up to $90 \%$ lasting for at least 72 hours was observed. Besides, a combination of siRNAs targeting different regions of the viral genome provided better inhibition of the target virus (Zheng et al., 2004). Moreover, siRNA-mediated knock down of actin-binding protein, ezrin, also provided protection against SARS infection in the entry stage (Millet et al., 2015).

\subsubsection{Convalescent plasma therapy}

Convalescent plasma therapy is a way of artificially inducing passive immunity by transferring blood plasma from patients who have had a disease to new patients. This can provide the recipient immunity towards the disease because of the antibodies present in the blood plasma. Convalescent plasmatherapy had increased the titres of neutralizing antibodies resulting in the disappearance of SARS-CoV- 
2 RNA, thus proving to be effective in reducing the disease timecourse finally leading to recovery (Rajendran et al., 2020). Hung et al. (2011) reported comparatively less death risk in patients treated with convalescent plasma during the H1N1-virus pandemic in 2009, proving it to be an effective therapy against coronaviruses as well. It was observed that in the acute phase of infection, the antibodies can limit coronavirus reproduction helping in rapid recovery of the patients (Ni et al., 2020).

\subsubsection{Oxygen therapy}

Hypoxemia is a condition where oxygen concentration in arterial blood comes below the normal range of 85 to $100 \mathrm{~mm} \mathrm{Hg}$. It is defined by the British Thoracic Society as $\mathrm{PaO}_{2}<60 \mathrm{~mm} \mathrm{Hg}$ or $\mathrm{SaO}_{2}$ $<90 \%$ (Al-Shaqsi and Brockway, 2013). Oxygen therapy used for treatment of hypoxemia and can aid in the relief of respiratory symptoms caused by COVID-19. Hypoxemic patients should receive oxygen therapy immediately and maintain a blood oxygen saturation level $\left(\mathrm{SaO}_{2}\right)$ of at least $90 \%$ (in pregnant women, between 92 and 95\%) (Li et al., 2020). The Ministry of Health recommends oxygen therapy in patients with SARS and breathing difficulties, hypoxemia or shock (Pereira et al., 2020).

\subsubsection{Mesenchymal stem cells}

Mesenchymal stem cells (MSCs) are multipotent cells that are easily accessible and culturally expandable with genomic stability. MSCs are therapeutic cells that can be used in immunological disease due to their regenerative and anti-inflammatory capabilities (Fan et al., 2019). Al-Khawaga and Abdelalim (2020) conducted a systematic review of studies on acute lung injury and acute respiratory distress syndrome (ARDS), explaining the therapeutic role of MSCs. They argued that MSCs could be used to treat COVID-19 and that it may reduce the progression of severe cases.

\subsubsection{Passive immunotherapy}

The technique of intravenous immunoglobulin (IgIV) therapy consists of extracting antibodies from the blood of donors, already immunized, to be injected into another person's veins (Hughes et al., 2014). In 1950s, this monoclonal antibody-based method was introduced as a replacement therapy for patients with congenital antibody deficiency (Boros et al., 2005). Monoclonal antibodies directed to the $\mathrm{S}$ protein in SARS-CoV and MERS-CoV had shown promising results in vitro and in vivo, and could be effective against SARS-CoV-2 (Shanmugaraj et al., 2020). However, no monoclonal antibodies have been successfully marketed due to the large scale production of monoclonal antibodies being laborious, costly and time consuming.

\section{Conclusion}

While a complete understanding of the gene functions and evolution of coronaviruses is essential for handling the recent outbursts of SARS-CoV-2, knowledge of its pathogenicity and zoonotic transmission is crucial to prevent its future outbreaks. Though, considerable insights in these aspects have been obtained, still, the understandings are incomplete. That is why the present strategies are not full-proof in prevention or treatment of COVID-19. Several preventive and therapeutic options are available and more are under evaluation. The preventive alternatives include various types of vaccines and therapeutic alternatives include new as well as repurposed drugs. Some minor candidates such as micronutrients and phytochemicals have also gained importance as prophylactic applications against COVID-19 (Bellik et al., 2020). Meanwhile, considering recurring infection-waves, mainly due to frequent emergence of newer virus strains, several nations are considering options of coexistence. Of late, there is an overwhelming increase in research on this virus, where the latest technologies have been playing pivotal roles. The current emphasis on genomics-led research in coronavirus infection as well as in drug discovery, design and repurposing, would certainly prove to be highly fruitful and productive in future.

\section{Acknowledgements}

Research in the Department of Agricultural Biotechnology, AAU, Jorhat, is funded by Department of Biotechnology (DBT), Govt. of India, Department of Science and Technology, Govt. of India, and Indian Council of Agricultural Research, Govt. of India. NF and HD acknowledge studentship from DBT.

\section{Conflicts of interest}

The authors declare no conflicts of interest relevant to this article.

\section{References}

Ahmad, S.R. and Ghosh, P. (2020). Benefits of dietary sesame seed and flaxseed to strengthen immune system during COVID-19 pandemic and prevent associated comorbidities related health risks. Ann. Phytomed., 9(2):50-61.

Al-Khawaga, S. and Abdelalim, E.M. (2020). Potential application of mesenchymal stem cells and their exosomes in lung injury: An emerging therapeutic option for COVID-19 patients. Stem Cell Res. and Ther., 11(1):1-33.

Al-Shaqsi, S. and Brockway, B. (2013). ABC of oxygen therapy in acute care: Why? Who? How? New Zealand Medical Student Journal, 17.

Alvi, M.M.; Sivasankaran, S. and Singh, M. (2020). Pharmacological and nonpharmacological efforts at prevention, mitigation, and treatment for COVID-19. Journal of Drug Targeting, 28(7-8):742-754.

Anderson, R. M.; Fraser, C.; Ghani,A. C.; Donnelly, C.A.; Riley, S.; Ferguson, N.M.; Leung, G.M.; Lam, T.H. and Hedley, A.J. (2004). Epidemiology, transmission dynamics and control of SARS: The 2002-2003 epidemic. Philosophical Transactions of the Royal Society of London. Series B: Biological Sciences, 359(1447):1091-1105.

Armstrong, J.; Niemann, H.; Smeekens, S.; Rottier, P. and Warren, G. (1984). Sequence and topology of a model intracellular membrane protein, E1 glycoprotein, from a coronavirus. Nature, 308(5961):751-752.

Ayal, B.; Gussow, N.A.; Guilhem, F.; Yuri, I.F.; Feng, Z. and Eugene, V.K. (2020). Genomic determinants of pathogenicity in SARS-CoV-2 and other human coronaviruses. PNAS, 117(26):15193-15199.

Beck, B.R.; Shin, B.; Choi, Y.; Park, S. and Kang, K. (2020). Predicting commercially available antiviral drugs that may act on the novel coronavirus (2019-nCoV), Wuhan, China through a drug-target interaction deep learning model. bioRxiv [Preprint]. doi: 10.1101/ 2020.01.31.929547.

Bellik, Y.; Bachir-Bey, M.; Fatmi, W.; Kouidri, M.; Souagui, Y; and Selles, S.M.A. (2020). Micronutrients and phytochemicals against COVID-19: Mechanism and molecular targets. Ann. Phytomed., 9(2):15-29.

Bharat Biotech, (2021). Bharat Biotech Announces Phase 3 Results of COVAXIN®: India's First COVID-19 Vaccine Demonstrates Interim Clinical Efficacy of $81 \%$. https://www.bharatbiotech.com/images/ press/covaxin-phase3-efficacy-results.pdf. Accessed on 10th October 2021 
Bjerrum, E.J. and Sattarov, B. (2018). Improving chemical autoencoder laten space and molecular de novo generation diversity with heteroencoders. Biomolecules, 8(4):131.

Boros, P.; Gondolesi, G. and Bromberg, J.S. (2005). High dose intravenous immunoglobulin treatment: Mechanisms of action. Liver Transplantation, 11(12):1469-1480

Callaway, E. (2021). Fast-spreading COVID variant can elude immune responses. Nature, 589:500-501.

Cascella, M.; Rajnik, M.; Cuomo, A.; Dulebohn, S.C. and Di Napoli, R. (2020). Features, evaluation and treatment coronavirus (COVID-19). StatPearls Publishing, Napo, Italy.

Chan, S.W. (2020). Current and future direct-acting antivirals against COVID-19. Front. Microbiol., 11:2880.

Chang, C.K.; Sue, S.C.; Yu, T.H.; Hsieh, C.M.; Tsai, C.K.; Chiang, Y.C.; Lee, S.J.; Hsiao, H.H.; Wu, W.J.; Chang, W.L. and Lin, C.H. (2006). Modular organization of SARS coronavirus nucleocapsid protein. J. Biomed. Sci., 13(1):59-72.

Chen, W.H.; Strych, U.; Hotez, P.J. and Bottazzi, M.E. (2020). The SARS-CoV-2 vaccine pipeline: An overview. Curr. Trop. Med. Rep., 7(20):6164.

Chenthamarakshan, V.; Das, P.; Hoffman, S.C.; Strobelt, H.; Padhi, I.; Lim, K.W. and Mojsilovic, A. (2020). Cogmol: Target-specific and selective drug design for COVID-19 using deep generative models. ArXiv, preprint 2004.01215 .

Chi, X.; Yan, R.; Zhang, J.; Zhang, G.; Zhang, Y.; Hao, M.; Zhang, Z.; Fan, P.; Dong, Y.; Yang, Y.; Chen, Z.; Guo, Y.; Zhang, J.; Li, Y.; Song, X.; Chen, Y.; Xia, L.; Fu, L.; Hou, L.; Xu, J.; Yu, C.; Li, J.; Zhou, Q. and Chen, W. (2020). A neutralizing human antibody binds to the $\mathrm{N}$-terminal domain of the spike protein of SARS-CoV-2. Science, 369:650-655.

Cui, L.; Wang, H.; Ji, Y.; Yang, J.; Xu, S.; Huang, X.; Wang, Z.; Qin, L.; Tien, P.; Zhou, X. and Guo, D. (2015). The nucleocapsid protein of coronaviruses acts as a viral suppressor of RNA silencing in mammalian cells. J. Virol., 89(17):9029-9043.

De Groot, R.J.; Luytjes, W.; Horzinek, M.C.; Van der Zeijst, B.A.M.; Spaan, W.J.M. and Lenstra, J.A. (1987). Evidence for a coiled-coil structure in the spike proteins of coronaviruses. J. Mol. Bio., 196(4):963-966.

Fan, X.L.; Zhang, Z; Ma, C.Y. and Fu, Q.L. (2019). Mesenchymal stem cells for inflammatory airway disorders: promises and challenges. Biosci. Rep., 39 (1)

Faria, N.R.; Claro, I.M.; Candido, D.; Franco, L.A.M.; Andrade, P.S.; Coletti, T.M.; Silva, C.A.M.; Sales, F.C.; Manuli, E.R.; Aguiar, R.S.; Gaburo, N.; Camilo, C.C.; Fraiji, N.A.; Crispim, M.A.E.; Carvalho, M.P.S.S.; Rambaut, A.; Loman, N.; Pybus, O.G. and Sabino, E.C. on behalf of CADDE Genomic Network. (2021). Genomic characterisation of an emergent SARS-CoV-2 lineage in Manaus: preliminary findings. Virol., 372:815-821.

Fehr, A.R. and Perlman, S. (2015). Coronaviruses: An overview of their replication and pathogenesis. Methods Mol. Bio., 1282:1-23.

Felgenhauer, U.; Schoen, A.; Gad, H.H.; Hartmann, R.; Schaubmar, A.R.; Failing, K.; Drosten, C. and Weber, F. (2020). Inhibition of SARS-CoV-2 by type I and type III interferons. J. Biol. Chem., 295:13958-13964.

Finkel, Y.; Mizrahi, O.; Nachshon, A.; Weingarten-Gabbay, S.; Morgenstern, D.; Yahalom-Ronen, Y.; Tamir, H.; Achdout, H.; Stein, D.; Israeli, O. and Beth-Din, A. (2021). The coding capacity of SARS-CoV-2. Nature, 589(7840): 125-130.

Fontanet,A.; Autran, B.; Lina, B.; Kieny, M.P.; Karim, S.S.A. and Sridhar, D. (2021) SARS-CoV-2 variants and ending the COVID-19 pandemic. The Lancet, 397(10278):952-954.
Fouchier, R.; Kuiken, T.; Schutten, M.; Amerongen, G.; Doornum, G.J.J.; Hoogen, B.G.; Peiris, M.; Lim, W.; Stöhr, K. and Osterhaus A.D.M.E. (2003). Koch's postulates fulfilled for SARS virus. Nature, 423:240.

Ge, X.Y.; Li, J.L.; Yang, X.L.; Chmura, A.A.; Zhu, G.; Epstein, J.H.; Mazet, J.K.; Hu, B.; Zhang, W.; Peng, C.; Zhang, Y.J.; Luo, C.M.; Tan, B.; Wang, N.; Zhu, Y.; Crameri, G.; Zhang, S.Y.; Wang, L.F.; Daszak, P. and Shi, Z.L. (2013). Isolation and characterization of a bat SARS-like coronavirus that uses the ACE2 receptor. Nature, 503(7477):535-538.

Gilardin, L.; Bayry, J. and Kaveri, S.V. (2015). Intravenous immunoglobulin as clinical immune-modulating therapy. Can. Med. Assoc. J., 187(4):257-264.

Gordon, D.E.; Jang, G.M.; Bouhaddou, M.; Xu, J.; Obernier, K.; White, K.M.; O'Meara, M.J.; Rezelj VV.; Guo J.Z; Swaney D.L.; Tummino T.; Hüttenhain R.; Kaake R.M.; Richards A.L.; Tutuncuoglu B.; Foussard H.; Batra J.; Haas K.; Modak, M.; Kim, M. (2020). A SARS-CoV-2 protein interaction map reveals targets for drug repurposing. Nature, 583:459-468.

Gordon, D.E.; Hiatt, J.; Bouhaddou, M.; Rezelj, V.V.; Ulferts, S.; Braberg, H.; Jureka, A.S.; Obernier, K.; Guo, J.Z; Batra, J.; Kaake, R.M.; Weckstein, A.R.; Owens, T.W.; Gupta, M.; Pourmal, S.; Titus, E.W.; Cakir, M.; Soucheray, M.; McGregor, M.; Cakir, Z. (2020). Comparative host-coronavirus protein interaction networks reveal pan-viral disease mechanisms. Science, 370:6521.

Grifoni, A.; Sidney, J.; Zhang, Y.; Scheuermann, R.H.; Peters, B. and Sette,A. (2020). A sequence homology and bioinformatic approach can predict candidate targets for immune responses to SARS-CoV-2. Cell Host Microbe, 27:671-680.

Guan, Y.; Zheng, B.J.; He, Y.Q.; Liu, X.L.; Zhuang, Z.X.; Cheung, C.L.; Luo; Li, P.H.; Zhang, L.J.; Guan, Y.J.; Butt, K.M.; Wong, K.L.; Chan, K.W.; Lim, W.; Shortridge, K.F.; Yuen, K.Y.; Peiris, J.S. and Poon, L.L. (2003). Isolation and characterization of viruses related to the SARS coronavirus from animals in southern China. Science, 302:276-278.

Gupta, R.; Paswan, R.R.; Saikia, R. and Borah B.K. (2020). Insights into the severe acute respiratory syndrome coronavirus-2: Transmission, genome composition, replication, diagnostics and therapeutics. Curr. J. Appl. Sci. Technol., 39(21):71-91.

Han, Y.; Duan, X.; Yang, L.; Nilsson-Payant, B.E.; Wang, P.; Duan, F; Tang, X.; Yaron, T.M.; Zhang, T.; Uhl, S.; Bram, Y.; Richardson, C.; Zhu, J.; Zhao, Z; Redmond, D.; Houghton, S.; Nguyen, D.T.; Xu, D.; Wang, X.; Jessurun, J. (2021). Identification of SARS-CoV-2 inhibitors using lung and colonic organoids. Nature, 589:270-275.

Hon, C.C.; Lam, T.Y.; Shi, Z.L.; Drummond,A.J.; Yip, C.W.; Zeng, F.; Lam, P.Y. and Leung, F.C. (2008). Evidence of the recombinant origin of a bat severe acute respiratory syndrome (SARS)-like coronavirus and its implications on the direct ancestor of SARS coronavirus. J. Virol., 82:1819-1826

Huang, C.; Wang, Y.; Li, X.; Ren, L.; Zhao, J.; Hu, Y. and Cao, B. (2020). Clinical features of patients infected with 2019 novel coronavirus in Wuhan, China. The Lancet, 395(10223):497-506.

Hufsky, F.; Lamkiewicz, K.; Almeida, A.; Aouacheria, A.; Arighi, C.; Bateman, A.; Baumbach, J.; Beerenwinkel, N.; Brandt, C.; Cacciabue, M.; Chuguransky, S.; Drechsel, O.; Finn, R.D.; Fritz, A.; Fuchs, S.; Hattab, G; Hauschild, A.C.; Heider, D.; Hoffmann, M.; Hölzer, M. (2021). Computational strategies to combat COVID-19: useful tools to accelerate SARS-CoV-2 and coronavirus research. Brief. Bioinform., 22(2):642-663.

Hughes, R.A.; Swan, A.V. and van Doorn, P.A. (2014). Intravenous immunoglobulin for Guillain-Barré syndrome. Cochrane Database of Systematic Reviews, 9.

Hung, I.F.; To, K.K.; Lee, C.K.; Lee, K.L.; Chan, K.; Yan, W.W.; Liu, R.; Watt, C.L.; Chan, W.M.; Lai, K.Y.; Koo, C.K.; Buckley, T.; Chow, K F.L.; Wong, K.; Chan, H.S.; Ching, C.K.; Tang, B.S.; Lau, C.C.; Li, I.W.; Liu, S.H.; Chan, K.H.; 
Lin, C.K. and Yuen K.Y. (2011). Convalescent plasma treatment reduced mortality in patients with severe pandemic influenza A (H1N1) 2009 virus infection. Clin. Infect. Dis., 52(4):447-456.

Irwin, J.J. and Shoichet, B.K. (2005). ZINC - A free database of commercially available compounds for virtual screening. J. Chem. Inf. Model, 45(1): $177-182$

Jaafar, Z.A. and Kieft, J.S. (2019). Viral RNA structure-based strategies to manipulate translation. Nat. Rev. Microbiol., 17(2):110-123.

Jaimes, J.A.; André, N.M.; Chappie, J.S.; Millet, J.K. and Whittaker, G.R. (2020). Phylogenetic analysis and structural modeling of SARS-CoV-2 spike protein reveals an evolutionary distinct and proteolytically sensitive activation loop. J. Mol. Biol., 432(10):3309-3325.

Ju, B.; Thang, Q.; Ge, J.; Wang, R.; Sun, J.; Ge, X.; Yu, J.; Shan, S.; Zhou, B.; Song S.; Tang, X.; Yu, J.; Lan, J.; Yuan, J.; Wang, H.; Zhao, J.; Zhang, S.; Wang, Y.; Shi, X.; Liu, L.; Zhao, J.; Wang, X.; Zhang Z. and Zhang L. (2020). Human neutralizing antibodies elicited by SARS-CoV-2 infection. Nature, 584:115-119.

Kaur, S.P. and Gupta, V. (2020). COVID-19 Vaccine: A comprehensive status report. Virus Res., 198114

Khadraoui, M. (2020). Repurposing bioinformatics tools to tackle the pandemic. Originally published on EMBL-EBI News. Science, 30.

Khan, A.A.; Khan, S.; Khan, U. and Das, K. (2020). The COVID-19 pandemic: A scoping review. Ann. Phytomed, 9(1):18-26.

Kim, S.; Chen, J.; Cheng, T.; Gindulyte, A.; He, J.; He, S.; Li, Q.; Shoemaker, B.A. Thiessen, P.A.; Yu, B.; Zaslavsky, L.; Zhang, J. and Bolton E.E. (2019). PubChem 2019 update: Improved access to chemical data. Nucleic Acids Res., 47(D1):D1102-D1109.

Knoops, K.; Kikkert, M.; Worm, S.H.V.D.; Zevenhoven-Dobbe, J.C.; Van Der Meer, Y.; Koster, A.J.;Mommaas, A.M. and Snijder, E.J. (2008). SARS-coronavirus replication is supported by a reticulovesicular network of modified endoplasmic reticulum. PLoS Biol., 6(9):e226.

Krause, P.; Fleming, T.R.; Longini, I.; Henao-Restrepo, A.M.; Peto, R.; Dean, N.E.; Halloran, M.E.; Huang, Y.; Fleming, T.R.; Gilbert, P.B. and DeGruttola, V.(2020). COVID-19 vaccine trials should seek worthwhile efficacy. The Lancet, 396(10253):741-743

Kumar, V.; Jung, Y.S. and Liang, P.H. (2013). Anti-SARS coronavirus agents: A patent review (2008-present). Expert Opin. Ther. Pat., 23(10): $1337-1348$

Kyriakidis, N.C.; López-Cortés, A.; González, E.V.; Grimaldos, A.B. and Prado E.O. (2021). SARS-CoV-2 vaccines strategies: A comprehensive review of phase 3 candidates. NPJ Vaccines, 6:28.

Lau, S.K.; Li, K.S.; Huang, Y.; Shek, C.T.; Tse, H.; Wang, M.; Choi, G.K.Y.; Xu, H.; Lam, C.S.F.; Guo, R.; Chan, K.H.; Zheng, B.J.; Woo, P.C.Y. and Yuen K.Y. (2010). Ecoepidemiology and complete genome comparison of different strains of severe acute respiratory syndrome-related Rhinolophus bat coronavirus in China reveal bats as a reservoir for acute, self-limiting infection that allows recombination events. J. Virol., 84: 2808-2819.

Lau, S.K.; Woo, P.C.; Li, K.S.; Huang, Y.; Tsoi, H.W.; Wong, B.H.; Wong, S.S.; Leung, S.Y.; Chan, K.H. and Yuen, K.Y. (2005). Severe acute respiratory syndrome coronavirus-like virus in Chinese horseshoe bats. Proc. Natl. Acad. Sci. U. S. A., 102:14040-14045.

Lek, M.; Karczewski, K.J.; Minikel, E.V.; Samocha, K.E.; Banks, E.; Fennell, T. O'Donnell-Luria, A.H.; Ware, J.S.; Hill, A.J.; Cummings, B.B.; Tukiainen, T.; Birnbaum, D.P.; Kosmicki, J.A.; Duncan, L.E.; Estrada, K.; Zhao, F.; Zou, J. Pierce-Hoffman, E.; Berghout, J.; Cooper, D.N. (2016). Analysis of proteincoding genetic variation in 60,706 humans. Nature, 536:285-291.

Li, T.; Lu, H. and Zhang, W. (2020).Clinical observation and management of COVID-19 patients. Emerging Micro. Infect., 9(1):687-690.
Li, W.; Shi, Z; Yu, M.; Ren, W.; Smith, C.; Epstein, J.H.; Wang, H.; Crameri, G.; Hu, Z; Zhang,H.; Zhang, J.; McEachern, J.; Field,H.; Daszak, P.; Eaton, B.T.; Zhang, S. and Wang, L.F. (2005). Bats are natural reservoirs of SARS-Like coronaviruses. Science, 310:676-679.

Lim, H.X.; Lim, J.; Jazayeri, S.D.; Poppema, S. and Poh, C.L. (2021). Development of multi-epitope peptide-based vaccines against SARS-CoV-2. Biomed. J., 44(1):18-30.

Loutfy, M.R.; Blatt, L.M.; Siminovitch, K.A.; Ward, S.; Wolff, B.; Lho, H.; Pham, D.H.; Deif, H.; LaMere, E.A.; Chang, M. and Kain, K.C. (2003). Interferon alfacon-1 plus corticosteroids in severe acute respiratory syndrome: A preliminary study. J. Am. Med Assoc., 290(24):3222-3228.

Lu, R.; Zhao, X.; Li, J.; Niu, P.; Yang, B.; Wu, H.; Wang, W.; Song, H.; Huang, B.; Zhu, N.; Bi, Y.; Ma, X.; Zhan, F.; Wang, L.; Hu, T.; Zhou,H.; Hu, Z.; Zhou, W.; Zhao, L. and Chen, J. (2020). Genomic characterisation and epidemiology of 2019 novel coronavirus: implications for virus origins and receptor binding. Lancet., 395:565-574.

Lundstrom, K. (2020). Coronavirus pandemic-therapy and vaccines. Biomedicines, 8(5):109.

Mackay, I.M. and Arden, K.E. (2015). MERS coronavirus: Diagnostics, epidemiology and transmission. Virol. J., 12(1):1-21.

McIntosh, K. and Peiris, J.S.M. (2009). Coronaviruses. Clinical Virology. $3^{\text {rd }}$ ed. American Society of Microbiology, pp:1155e71.

Mehrotra, M. (2020). Medicinal plants, aromatic herbs and spices as potent immunity defenders: Antiviral (COVID-19) perspectives. Ann. Phytomed. 9(2):30-49.

Mei, M. and Tan, X. (2021). Current Strategies of Antiviral Drug Discovery for COVID-19. Front. Mol.Biosci., 8:310

Millet, J.K. and Nal, B. (2015). Investigation of the functional roles of host cell proteins involved in coronavirus infection using highly specific and scalable RNA interference (RNAi) approach. In: Coronaviruses. Humana Press, New York, NY231-240.

Moderna, C. (2020). Moderna Announces Funding Award from CEPI to Accelerate Development of Messenger RNA (mRNA) Vaccine Against Novel Coronavirus. https://investors.modernatx.com/newsreleases/news-release-details/moderna-announces-funding-awardcepi-accelerate-development. Accessed on 10th October 2021.

Morens, D.M.; Breman, J.G.; Calisher, C.H.; Doherty, P.C.; Hahn, B.H.; Keusch, G.T.; Kramer, L.D.; LeDuc, J.W.; Monath , T.P. and Taubenberger J.K. (2020). The origin of COVID-19 and why it matters. Am. J. Trop. Med. Hygiene, 103(3):955.

Neuman, B.W.; Kiss, G; Kunding,A.H.; Bhella, D.; Baksh, M.F.; Connelly, S.; Droese, B.; Klaus, J.P.; Makino, S.; Sawicki, S.G. and Siddell, S.G. (2011). A structural analysis of $\mathbf{M}$ protein in coronavirus assembly and morphology. $\mathbf{J}$. Struct. Biol., 174(1):11-22.

Ng, W.H.; Liu, X. and Mahalingam, S. (2020). Development of vaccines for SARS-CoV-2. F1000 Res., 991.

Ni,L.; Ye, F.; Cheng, M.L.; Feng, Y.; Deng, Y.Q.; Zhao, H.; Wei, P.; Ge, J.; Gou, M.; Li, X. and Sun, L. (2020).Detection of SARS-CoV-2-specific humoral and cellular immunity in COVID-19 convalescent individuals. Immunity, 52(6): 971-977.

Novelli, G.; Biancolella, M.; Mehrian-Shai, R.; Colona, V,L.; Brito, A,F.; Grubaugh, N,D.; Vasiliou, V.; Luzzatto, L.; and Reichardt J,K,V. (2021). COVID-19 one year into the pandemic: from genetics and genomics to therapy, vaccination, and policy. Hum, Genomics, 15:27.

Ortega, J.T.; Serrano, M.L.; Pujol, F.H. and Rangel, H.R. (2020).Unrevealing sequence and structural features of novel coronavirus using in silico approaches: The main protease as molecular target. Excli J., 19:400409.

Ortego, J.; Escors, D.; Laude, H. and Enjuanes, L. (2002). Generation of a replication-competent, propagation-deficient virus vector based on the transmissible gastroenteritis coronavirus genome. J. of virol., 76(22): 11518-11529. 
Palai, S.; Dehuri, M. and Patra, R. (2020). Spices boosting immunity in COVID19. Ann. Phytomed. 9(2):80-96.

Park, S.J.; Kim, Y.G. and Park, H.J. (2011). Identification of RNA pseudoknotbinding ligand that inhibits the" 1 ribosomal frameshifting of SARScoronavirus by structure-based virtual screening. J. Am. Chem. Soc., 133(26): 10094-10100.

Parveen, S. and Alnoman, R.B. (2021). Potential exploration of recent FDAapproved anticancer drugs against models of SARS-CoV-20 s main protease and spike glycoprotein: A computational study. Biointerface Res. Appl., 11:10059-10073.

Patrick, C.Y.; Huang, W.Y.; Lau, S.K.P. and Yuen, K.Y. (2010). Coronavirus Genomics and Bioinformatics Analysis. Viruses, 2:1804-1820.

Peeri, N.C.; Shrestha, N.; Rahman, M.S.; Zaki , R.; Tan, Z.; Bibi , S.; Baghbanzadeh , M.; Aghamohammadi , N.; Zhang, W. and Haque, U.; (2020). The SARS, MERS and novel coronavirus (COVID-19) epidemics, the newest and biggest global health threats: What lessons have we learned? Int. J. Epidemiol., 49(3):717-726.

Pelly, S. and Liotta, D. (2021). Potent SARS-CoV-2 direct-acting antivirals provide an important complement to COVID-19 vaccines. ACS Cent Sci., 7(3):396-399.

Pereira, A.A.; de Oliveira Andrade, A.; de Andrade Palis, A.; Cabral, A.M.; Barreto, C.; de Souza, D.B.; de Paula Silva, F.; Santos, F.P.; Silva, G.L.; Guimarães, J.; de Araújo, L.; Nóbrega, L.R.; Mendes, L.C.; Brandão, M.R.; Milagre, S.T.; de Lima Gonçalves, V.; de Freitas Morales, V.H. and da Conceição Lima, V. (2021). Non-pharmacological treatments for COVID-19: current status and consensus. Research on Biomed. Eng., pp:1-16.

Perez, S.A.; Kallinteris, N.L.; Bisias, S.; Tzonis, P.K.; Georgakopoulou, K.; VarlaLeftherioti, M.; Papamichail, M.; Thanos, A.; von Hofe, E. and Baxevanis, C.N. (2010). Results from a phase I clinical study of the novel Ii-Key/ HER-2/neu (776-790) hybrid peptide vaccine in patients with prostate cancer. Clin. Cancer Res., 16(13):3495-3506.

Perlman, S. and Netland, J. (2009). Coronaviruses post-SARS: Update on replication and pathogenesis. Nat. Rev. Microbiol., 7:439-450.

Plant, E.P. and Dinman, J.D. (2008). The role of programmed-1 ribosomal frameshifting in coronavirus propagation. Frontiers in Bioscience: a Journal and Virtual Library, 13:4873.

Plante, J.A.; Mitchell, B.M.; Plante, K.S.; Debbink, K.; Weaver, S.C. and Menachery V.D. (2021). The variant gambit: COVID's next move. Cell Host Microbe, 29(4):508-515.

Poon, L.L.M.; Chu, D.K.W.; Chan, K.H.; Wong, O.K.; Ellis, T.M.; Leung, Y.H.C.; Lau, S.K.P.; Woo, P.C.Y.; Suen, K.Y.; Yuen, K.Y. and Peiris, J.S. (2005). Identification of a novel coronavirus in bats. J. Virol., 79:2001-2009.

Poveda, E.; Wyles, D.L.; Mena, Á.; Pedreira, J.D.; Castro-Iglesias, Á. and Cachay, E. (2014). Update on hepatitis $\mathrm{C}$ virus resistance to direct-acting antiviral agents. Antiviral Research, 108:181-191.

Prompetchara, E.; Ketloy, C. and Palaga, T. (2020). Immune responses in COVID-19 and potential vaccines: Lessons learned from SARS and MERS epidemic. Asian Pac. J. Allergy Immunol., 38(1):1-9.

Pyrc, K.; Dijkman, R.; Deng, L.; Jebbink, M.F.; Ross, H.A.; Berkhout, B. and van der Hoek, L. (2006). Mosaic structure of human coronavirus NL63, one thousand years of evolution. J. Mol. Biol., 364:964-973.

Qian, Z.; Travanty, E.A.; Oko, L., Edeen, K.; Berglund, A.; Wang, J.; Ito, Y.; Holmes, K.V. and Mason, R.J. (2013). Innate immune response of human alveolar type ii cells infected with severe acute respiratory syndromecoronavirus. Am. J. Respirat. Cell Mol. Biol., 48(6):742-748.

Rajendran, K.; Krishnasamy, N.; Rangarajan, J.; Rathinam, J.; Natarajan, M. and Ramachandran, A. (2020). Convalescent plasma transfusion for the treatment of COVID 19: Systematic review. J. Med. Virol., 92(9): 1475-1483.
Rangan, R.; Zheludev, I.N.; Hagey, R.J.; Pham, E.A.; Wayment-Steele, H.K.; Glenn, J.S. and Das, R. (2020). RNA genome conservation and secondary structure in SARS-CoV-2 and SARS-related viruses: a first look. RNA, 26(8):937-959.

Riva, L.; Yuan, S.; Yin, X.; Martin-Sancho, L.; Matsunaga, N.; Pache, L. and Chanda, S.K. (2020). Discovery of SARS-CoV-2 antiviral drugs through largescale compound repurposing. Nature, 586(7827): 113-119.

Romano, M.; Ruggiero, A.; Squeglia,F.; Maga, G. and Berisio, R. (2020). A structural view of SARS-CoV-2 RNA replication machinery: RNA synthesis, proofreading and final capping. Cells, 9(5):1267.

Saini, P. (2020). COVID-19 pandemic: potential phase III vaccines in development. T Appl. Biol. Chem. J., 1(1):21-33.

Seesuay, W.; Jittavisutthikul, S.; Sae-Lim, N.; Sookrung, N.; Sakolvaree, Y. and Chaicumpa, W. (2018). Human transbodies that interfere with the functions of Ebola virus VP35 protein in genome replication and transcription and innate immune antagonism. Emerging Micro. Infect., 7(1):1-15.

Shanmugaraj, B.; iriwattananon, K.; Wangkanont, K. and Phoolcharooen, W. (2020). Perspective on monoclonal antibody therapy as potential therapeutic intervention for coronavirus disease-19 (COVID-19). Asian Pac. J. Allergy Immunol., 38:10-8.

Shirley, J.L.; de Jong, Y.P.; Terhorst, C. and Herzog, R.W. (2020). Immune responses to viral gene therapy vectors. Mol. Ther., 28(3):709722.

Sinovac. (2021). http://www.sinovac.com/?optionid=754\&auto_id=922. Accessed on 10th October 2021.

Smith, R.D. (2006). Responding to global infectious disease outbreaks: lessons from SARS on the role of risk perception, communication and management. Soc. Sci. Med., 63(12): 3113-3123.

Stammler, S.N.; Cao, S.; Chen, S.J. and Giedroc, D.P. (2011). A conserved RNA pseudoknot in a putative molecular switch domain of the 32 untranslated region of coronaviruses is only marginally stable. RNA, 17(9):1747-1759.

Stebbing, J.; Krishnan, V.; de Bono, S.; Ottaviani, S.; Casalini, G.; Richardson, P.J.; Monteil, V.; Lauschke, V.M.; Mirazimi, A.; Youhanna, S.; Tan, Y.J.; Baldanti, F.; Sarasini, A.; Terres, J.A.R.; Nickoloff, B.J.; Higgs, R.E.; Rocha, G.; Byers, N.L.; Schlichting, D.E.; Nirula, A.; Cardoso, A.; Corbellino, M. and Sacco Baricitinib Study Group. (2020). Mechanism of baricitinib supports artificial intelligence-predicted testing in COVID-19 patients. EMBO Mol. Med., 12:e12697.

Sun, L.; Li, P.; Ju, X.; Rao, J.; Huang, W.; Ren, L.; Zhang, S.; Xiong, T.; Xu, K.; Zhou, X.; Gong, M.; Miska, E.; Ding, Q.; Wang, J. and Zhang, Q.C. (2021). In vivo structural characterization of the SARS-CoV-2 RNA genome identifies host proteins vulnerable to repurposed drugs. Cell, 184:1865-1883.e20.

Tang, B.; He, F.; Liu, D.; Fang, M.; Wu, Z. and Xu D. (2020). AI-aided targeted covalent inhibitors design against SARAS-COV-2. bioRxiv.

Tebas, P.; Yang, S.; Boyer, J.D.; Reuschel, E.L.; Patel, A.; Christensen-Quick, A.; Andrade, V.M.; Morrow, M.P.; Kraynyak, K.; Agnes, J. and Purwar, M. (2021). Safety and immunogenicity of INO-4800 DNA vaccine against SARS-CoV-2: A preliminary report of an open-label, Phase 1 clinical trial. EClinical Medicine, 31:100689.

Tizaoui, K.; Zidi, I.; Lee, K.H.; Ghayda, R.A.; SHong, .H.; Li, H.; Smith, L.; Koyanagi, A.; Jacob, L.; Kronbichler A. and Shin. J.I. (2020). Update of the current knowledge on genetics, evolution, immunopathogenesis, and transmission for coronavirus disease 19 (COVID-19). Int. J. Biol. Sci., 16:2906-2923.

Vijaykrishna, D.; Smith, GJ.; Zhang, J.X.; Peiris, J.S.; Chen, H. and Guan, Y. (2007). Evolutionary insights into the ecology of coronaviruses. J. Virol., 81:4012-4020. 
Vijgen, L.; Keyaerts, E.; Lemey, P.; Maes, P.; Van Reeth, K.; Nauwynck, H.; Pensaert, M. and Van Ranst, M. (2006). Evolutionary history of the closely related group 2 coronaviruses: porcine hemagglutinating encephalomyelitis virus, bovine coronavirus, and human coronavirus OC43. J. Virol., 80:7270-7274.

Villas-Boas, G.R.; Rescia, V.C.; Paes, M.M.; Lavorato, S.N.; Magalhães-Filho, M.F.; Cunha, M.S.; Simões, R.C.; Lacerda, R.B.; Freitas-Júnior, R.S.; Ramos, B.H.D.S.; Mapeli, A.M.; Henriques, M.D.S.T.; Freitas, W.R.; Lopes, L.A.F.; Oliveira, L.G.R.; Silva, J.G.D.; Silva-Filho, S.E.; Silveira, A.P.S.D.; Leão, K.V. and Matos, M.M.S. (2020). The New Coronavirus (SARS-CoV-2): A Comprehensive Review on Immunity and the Application of Bioinformatics and Molecular Modeling to the Discovery of Potential Anti-SARS-CoV-2 Agents. Molecules, 25:4086.

Wan, Y.; Shang, J.; Graham, R.; Baric, R.S. and Li, F. (2020). Receptor recognition by the novel coronavirus from Wuhan: An analysis based on decade-long structural studies of SARS coronavirus. J. Virol., 94(7): e00127-20.

Weinreich, D.M.; Sivapalasingam, S.; Norton, T.; Ali, S.; Gao, H.; Bhore, R.; Musser B.J.; Soo, Y.; Rofail, D.; Im, J.; Perry, C.; Pan, C.; Hosain, R.; Mahmood, A. Davis, J.D.; Turner, K.C.; Hooper,A.T.; Hamilton, J.D.; Baum,A. and Kyratsous, C.A. (2021). REGN-COV2, a neutralizing antibody cocktail, in outpatients with covid-19. N. Engl. J. Med., 384:238-251.

Wibmer, C.K.; Ayres, F.; Hermanus, T.; Madzivhandila, M.; Kgagudi, P.; Oosthuysen, B.; Lambson, B.E.; de Oliveira, T.; Vermeulen, M.; van der Berg, K.; Rossouw, T.; Boswell, M.; Ueckermann, V.; Meiring, S.; von Gottberg, A.; Cohen, C.; Morris, L.; Bhiman, J.N. and Moore, P.L. (2021). SARS-CoV-2 501Y. V2 escapes neutralization by South African COVID-19 donor plasma. Nat. Med., 27(4), 622-625.

Xia, S.; Duan, K.; Zhang, Y.; Zhao, D.; Zhang, H.; Xie, Z.; Li, X.; Peng, C., Zhang, Y.; Zhang, W. and Yang, Y. (2020). Effect of an inactivated vaccine agains SARS-CoV-2 on safety and immunogenicity outcomes: interim analysis of 2 randomized clinical trials. J. Am. Med. Assoc., 324(10): 951-960.

Xia, S.; Zhang, Y.; Wang, Y.; Wang, H.; Yang, Y.; Gao, GF.; Tan, Wenjie.; Wu, Guizhen.; Xu, Miao.; Lou, Zhiyong.; Huang, Weijin .; Xu, Wenbo.; Huang, Baoying.; Wang, Huijuan.; Wang, Wei.; Zhang, Wei.; Li, Na.; Xie, Zhiqiang.; Ding, Ling and You, Wangyang. (2021). Safety and immunogenicity of an inactivated SARS-CoV-2 vaccine, BBIBPCorV: a randomised, double-blind, placebo-controlled, phase 1/2 trial. Lancet Infect. Dis., 21:39"51.
Yang, D. and Leibowitz, J.L. (2015). The structure and functions of coronavirus genomic 32 and 52 ends. Virus Res., 206:120-133.

Yang, L.; Liu, W.; Yu, X.; Wu, M.; Reichert, J.M. and Ho, M. (2020). COVID-19 antibody therapeutics tracker: a global online database of antibody therapeutics for the prevention and treatment of COVID19. Antibody Therapeutics, 3(3):205-212.

Zeng, X.; Zhu, S.; Hou, Y.; Zhang, P.; Li, L.; Li, J.; Huang, L.F.; Lewis, S.J.; Nussinov, R. and Cheng, F. (2020). Network-based prediction of drug-target interactions using arbitrary-order proximity embedded deep forest. Bioinformatics, 36:2805-2812.

Zhang, T.; Qunfu, W. and Zhigang, Z. (2020). Probable pangolin origin of SARSCoV-2 associated with the COVID-19 Outbreak. Curr Biol., 30:1-6.

Zhavoronkov,A.; Aladinskiy, V.; Zhebrak, A.; Zagribelnyy, B.; Terentiev, V.; Bezrukov, D. S. and Ivanenkov, Y. (2020). Potential 2019-nCoV 3C-like protease inhibitors designed using generative deep learning approaches. Chemrxiv, doi: 10.26434/chemrxiv.11829102.v2

Zheng, B.J.; Guan, Y.; Tang, Q.; Du, C.; Xie, F.Y.; He, M.L.; Chan, K.W.; Wong, K.L.; Lader, E.; Woodle, M.C. and Lu, P.Y. (2004). Prophylactic and therapeutic effects of small interfering RNA targeting SARS coronavirus. Antiviral Therapy, 9(3): 365-374.

Zhou, P.; Yang, X.L.; Wang, X.G.; Hu, B.; Zhang, L.; Zhang, W.; Si, H.R.; Zhu, Y.; Li, B.; Huang, C.L. and Chen, H.D. (2020). A pneumonia outbreak associated with a new coronavirus of probable bat origin. Nature, 579(7798):270-273

Zhou, Y.; Hou, Y.; Shen, J.; Huang, Y.; Martin, W. and Cheng, F. (2020).Networkbased drug repurposing for novel coronavirus 2019-nCoV/SARS-CoV-2. Cell Discov., 6:14.

Zhu, L.; Yang, P.; Zhao, Y.; Zhuang, Z.; Wang, Z.; Song, R.; Zhang, J.; Liu, C.; Gao, Q.; Xu, Q. and Wei, X. (2020). Single-cell sequencing of peripheral mononuclear cells reveals distinct immune response landscapes of COVID-19 and influenza patients. Immunity, 53(3):685-696.

Zhu, W.; Chen, C.Z.; Gorshkov, K.; Xu, M.; Lo, D.C. and Zheng, W. (2020). RNAdependent RNA polymerase as a target for COVID-19 drug discovery. SLAS Discov., 25(10):1141-1151.

Namrata Farwaha, Himangana Das, Richita Saikia, Ricky Raj Paswan, Munmi Phukon, Rashmi Rekha Baruah, Ratna Kalita, Priyadarshini Bhorali, Basanta Kumar Borah and Tankeswar Nath (2021). Genomics-led insight into the coronavirus evolution, pathogenicity and management. Ann. Phytomed., Volume10, Special Issue2 (COVID19): S86-S97. http://dx.doi.org/10.54085/ap.covid19.2021.10.2.10 